\title{
THE POOR, THE UNEMPLOYED AND THE PUBLIC WORKER - A COMPARATIVE ESSAY ON NATIONAL UNEMPLOYMENT POLICIES CONTRIBUTION TO DEEPENING POVERTY
}

\author{
Sara Hungler ${ }^{1}$ \\ Faculty of Law and Political Sciences, Eotvos \\ Lorand University of Sciences, Hungary \\ email: hungler@ajk.elte.hu
}

HUNGLER, Sara. The Poor, the Unemployed and the Public Worker - A Comparative Essay on National Unemployment Policies Contribution to Deepening Poverty . International and Comparative Law Review, 2012, Vol. 12., No. 1, pp. 123-140. DOI: 10.1515/iclr-2016-0082.

\begin{abstract}
The aim of this article is to discuss the relation between a state's unemployment and social policies with an eye on rights and duties declared in the European Social Charter and the Revised European Social Charter. First a summary is given to major international human right instruments' approach to forced labor in connection with public work programs, followed by an introduction to Article 1(2) of the European Social Charter and its interpretation by the European Committee of Social Rights. This section will also give a short comparative analysis on the unemployment policies of selected EU Member States. The second half of the article is dedicated to the past and present of the Hungarian public work program and its critical analysis.
\end{abstract}

Keywords: unemployment policy, social policy, European Social Charter, Hungary, EU Member states, forced labour

\section{Introduction}

A recently published research of Eurostat revealed striking data: in 2010 around $23 \%$ of the European population were considered to be at risk of poverty or social exclusion (AROPE) ${ }^{2}$. Data show that $16 \%$ of the European population

1 The author is a Ph.D. candidate of Eotvos Lorand University of Sciences, Faculty of Law and Political Sciences, Department of Labor and Social Law. I am most grateful to Professor Csilla Kollonay-Lehoczky for her enormous help and insightful comments.

2 According to the definition adopted for the Europe 2020 strategy, the AROPE indicator is defined as the share of the population in at least one of the following three conditions: 1 ) at risk of poverty, meaning below the poverty threshold, 2) in a situation of severe material 
were at risk of poverty, meaning below the poverty threshold, $8 \%$ of Europeans were severely materially deprived ${ }^{3}$ and $36 \%$ stated they would be unable to cope with unexpected expenses ${ }^{4}$. Around $10 \%$ of people aged $0-59$ could be considered as living in a household with very low work intensity in $2010^{5,6}$. The report mentions Hungary as one the extreme examples with its $30 \%$ of AROPE rate. According to data from the Hungarian Central Statistical Office, around one-fifth of the population between the ages of 20-59, the equivalent of 1 million people, is permanently unemployed, and $3 \%$ of the active population lives in deep poverty ${ }^{7}$.

The worrisome data and the ongoing debate on the new Hungarian public work program triggered this article, which aims to discuss the relation between a state's unemployment and social policies with an eye on rights and duties declared in the European Social Charter and the Revised European Social Charter. First a summary is given to major international human right instruments' approach to forced labor in connection with public work programs, followed by an introduction to Article 1(2) of the European Social Charter and its interpretation by the European Committee of Social Rights. This section will also give a short comparative analysis on the unemployment policies of selected EU Member States. The second half of the article is dedicated to the past and present of the Hungarian public work program and its critical analysis.

\section{Forced labor and unemployment}

The connections between forced labor and the different schemes of unemployment services have been researched for many years. Attention has been paid to governmental measures aiming to curtail expenditure on unemployment benefits, either or both by cutting the social benefits paid to the unemployed or/and introducing some sort of public work programs. While the fiscal effect of the first solution does not require complex explanation, the latter one has been supported by different socio-economic theories.

The prohibition of forced and compulsory labor is governed by numerous international treaties, including the European Convention of Human Rights (ECHR), the EU Charter and the European Social Charter, and there is now

deprivation, 3) living in a household with a very low work intensity

3 Stable compared with 2009

4 An increase of 1 percentage point compared with 2009

5 An increase of 0.9 pp compared with 2009

6 Statistics in focus 9/2012 Population and social conditions; Authors: Mélina ANTUOFERMO and Emilio DI MEGLIO, Data extracted on: 16.12.2011, ISSN 1977-0316, Catalogue number: KS-SF-12-009-EN-N, Eurostat

7 Quoted by the research of Patriotism and Progress Public Policy Foundation: Mobility with joint forces http://www.hazaeshaladas.hu/ftp/hesh_paper_summary_eng_sent.pdf, retrieved on 10 May, 2012, p.3. 
wide recognition that both are prohibited under customary international law ${ }^{8}$. One approach has been to formulate it in a broad way as prohibition to perform any kind of forced or compulsory labor, followed by a list of exceptions. Article 8(3) of the International Covenant on Civil and Political Rights (ICCPR), Article 4(2) of the ECHR and Article 5(2) of the EU Charter follow this structure, stating equivocally that "no one shall be required to perform forced or compulsory labor". Other instruments have preferred to resort to a concisely expressed idea of 'free choice or acceptance of work or occupation'. Article 6(1) of the International Covenant on Economic, Social and Cultural Rights (ICESCR) provides: "State Parties to the present Convention recognize the right to work which includes the right of everyone to the opportunity to gain his living by work which he freely chooses or accepts" and Article 1(2) of the European Social Charter provides that "everyone shall have the opportunity to earn his living in an occupation freely entered upon".

The definition of forced or compulsory labor used in ECHR, the EU Charter and ICCPR is taken over from Convention No. 29 of the ILO of 1930, subsequently supplemented by another ILO Convention, the Abolition of Forced Labor Convention of 1957. According to the ILO definition, forced or compulsory labor is considered to be "all work or service which is extracted from any person under the menace of penalty and for which the said person has not offered himself voluntarily".

These definitions are based on two equally important elements: a work or a service to be performed and a threat of a penalty and involuntariness. The ILO Committee has explained the meaning of work or service by excluding compulsory education and vocational training, given it does not entail burdensome amount of practical work. Regarding the menace of penalty, the Committees standpoint is that it should be construed broadly, not restricting to forms of penal sanctions but including a loss of rights or privileges, such as a promotion, transfer, access to new employment, housing, etc ${ }^{9}$. Considerable attention has been devoted to this element, particularly over whether psychological coercion or economic compulsion might amount to a penalty within the meaning of the Forced Labor Convention.

The ILO supervisory bodies have recognized that psychological coercion might amount to the menace of a penalty, but have been hesitant to accept the argument that a general situation of economic constraint that keeps a worker on a job is equivalent to the menace of any penalty ${ }^{10}$. Instead, the Committee

8 Jacobs, White: The European Convention on Human Rights; Clarendon Press, Oxford, 1996 ISBN 0-19-825820-8; p. 70

9 Abolition of forced labour, General Survey of 1979, op. cit., at para. 21; see also Eradication of forced labour, General Survey of 2007, at para. 37.

10 See ILO, Report of the Committee set up to examine the Article 24 representation concerning Portugal, 1985, para. 97. 
has pointed out that the employer or State is "not accountable for all external constraints or indirect coercion existing in practice (...) [thus] the need to work in order to earn one's living could become relevant only in conjunction with other factors for which they are answerable"11. With regard to the element of voluntary offer, the Committee excludes all agreements concluded under threat or deceit and fraud are involved in the original work offer. Since a worker's right to free choice of employment is inalienable, a worker must always be free to choose to leave his or her work. With other words, the question here consists of two parts: whether the consent to work was in fact freely given, and whether the worker retains the ability to revoke his or her consent.

According to the ILO definition of forced or compulsory work, the work must be performed involuntarily, and the requirement to do work must be unjust or oppressive or the work itself involves avoidable hardship. On the flip side of such involuntary work, the ILO Committee of Experts on the Meaning of Forced Labor considered that a situation which involved allegation of eligibility for benefits being linked to compulsory acceptance of low-paying unsuitable jobs, where the compulsion stemmed from a scarcity of suitable jobs arising from general economic constraints, did not fall within the scope of the convention ${ }^{12}$.

When states extensively regulate the labor market, this obligation seems to gain practical importance though. While every general duty to work imposed by states that carries a penal sanction violates the prohibition of forced or compulsory work, the mere lapse of unemployment assistance when a person refuses to accept work not corresponding to his or her qualification does not, on the other hand, represent a violation. In this case neither the intensity of the involuntariness nor that of the sanction reaches the degree required for forced or compulsory labor ${ }^{13}$.

\section{The European Social Charter and the activity of the European Commi- ttee of Social Rights}

Due to its obviously inherent connection to social rights, questions regarding the lawfulness of the allocation of unemployment benefits often find their way to the European Committee of Social Rights. The European Committee of Social

11 ILO, Report of the Committee of Experts on the Application of Conventions and Recommendations, Report III (Part 1A), International Labour Conference, 90th Session, Geneva, 2002, p. 98.

12 Forced Labour and Human Trafficking; Casebook of Court Decisions. ISBN 978-92-2122177-7;978-92-2-122178-4 (web pdf), International Labour Office, 2009

13 Decision of the ECmHR in the Talmon-case: Talmon v. Netherlands No 30300/96 HUDOC (1997) DA cf, X v. Netherlands No. 7602/76, 7 DR 161 (1976) see also: Manfred Nowak: U.N. Covenant on Civil and Political rights, CCPR Commentary, 2005, Second revised edition, N.P. Engel, 2005 ISBN 3-88357-134-2, p. 202.; Harris, O’Boyle and Warbrick: Law of the European Convention on Human Rights, Oxford University Press, 2009, second edition ISBN: 978-0-40-69-594-9, p. 116. 
Rights supervises the conformity of the situation in Contracting States with their undertakings under the European Social Charter, or the Revised Charter. As a part of the supervisory system, the Committee of Social Rights, composed of fifteen independent experts elected by the Committee of Ministers and assisted by an observer from the ILO, examines the reports submitted by the States party to the Charter and makes a legal assessment of states observance of their obligations.

Article 1(2) of the European Social Charter guarantees the protection against forced labor, as it was described above, by a concisely expressed concept of 'free choice or acceptance of work or occupation' together with other practices that make up the freedom of work. Hence, the issue of loss of employment benefits for refusal to take up employment has soon become the center of interest of the Committee $^{14}$. During the fifteenth supervision cycle the Committee carried out in some cases examinations of measures taken by certain governments to support employment and reduce spending on employment benefits. It found that the use of such measures which could have a significant effect on the right to earn one's living in an occupation freely entered upon, was becoming increasingly frequent. In conclusions 2002 the Committee decided to examine this matter systematically for all states, also in the framework of Article $1(2)^{15}$.

\subsection{The interpretation of Article 1(2) - The right of the worker to earn his living in an occupation freely entered upon}

Under Article 1(2), the Contracting Parties undertake "to protect effectively the right of the worker to earn his living in an occupation freely entered upon". At the beginning, majority of the Committee's attention regarding the prohibition of forced labor was dedicated to the assessment of situations whereas different, even criminal sanctions were imposed on merchant navy or aviation workers, like excessive lengths of compulsory service, refusal of acceptance of resignation and organization or participation in strikes on board ${ }^{16}$. The Committee also examines situations contrary to the prohibition of forced labor on other grounds. Since the $15^{\text {th }}$ supervision cycle special attention has been given to the issue of loss of unemployment for refusal to take up employment offered - either on the primary labor market or within a public work scheme.

According to the Digest, "the Committee has found national situations to be in breach of the Charter: (...) - where unemployment and notably youth unemployment and long-term unemployment was extremely high and in the light of

14 European Social Charter (revised): European Committee of Social Rights: Conclusions XVI-1; Council of European Publishing

15 European Social Charter (revised): European Committee of Social Rights: Conclusions 2004 - vol. 2.; Council of European Publishing

16 Rich case law can be found in relations to Greece, United Kingdom, Turkey, Portugal, to name a few, in Conclusions. 
which the measures taken were insufficient $(. .$.$) ; - where there were negative$ developments in the employment policy, both in terms of activation of unemployed persons and overall expenditure, at a time when unemployment, despite economic growth, was increasing sharply" ${ }^{\prime 1}$.

The Committee has requested information on the obligation imposed on jobseekers to accept suitable work, the conditions under which their unemployment benefit was suspended or whereby they were required to perform socially useful work, the criteria to evaluate job-seekers bona fide and the suitability of their reasons where they refused to take up a certain employment or training ${ }^{18}$. The Committee has been further elaborated the sequence of questions asked on the loss of unemployment benefit and inquires "whether the right to unemployment benefit is conditional on the acceptance of employment or training. If so, it asks (i) what sanctions apply in case of refusal of employment or training, (ii) if refusal on that the employment does not correspond to the person's occupational qualifications is considered valid, (iii) for what duration employment may be refused on the basis that it does not correspond to occupational qualifications and (iv) if there is a right to appeal ${ }^{19}$.

Later on, the unemployment benefit issue was connected to the assessment of Article 12(1), under which the Contracting Parties undertake "to establish or maintain a system of social security". Under Article 12 of the Charter the right to social security encompasses the right to access and maintain benefits without discrimination in order to secure affordable health care; benefits in case of loss of earnings caused by sickness, unemployment, old age, employment injury, disability, and maternity and family support, particularly for children and adult dependents.

Regarding the conditions for the payment of unemployment benefits the Digest notes that „[t]he conditions to which the payment of unemployment benefits is subjected, including any obligations to take up offered employment is assessed under the right to social security provided by Article 12. However, where the constraint is particularly heavy it may give rise to an issue of conformity with Article $1(2)^{20}$.

17 Digest of the Case Law of the European Committee of Social Rights, 2008, p. 20.

18 Samuel, Lenia: Fundamental social rights - Case law of the European Social Charter, Council of Europe Publishing, 2002, ISBN 92-871-4932-5, p. 19.

19 Conclusions XVI-1 vol. 2, Luxembourg; Conclusions XVI-1 vol. 2, Malta; Conclusions XVI-1 vol. 2, Netherlands-Antilles; Conclusions XVI-1 vol. 2, Poland; Conclusions XVI-1 vol. 2, Portugal; Conclusions XVI-1 vol. 2, Spain; Conclusions XVI-1 vol. 2, Turkey; Conclusions XVI-1 vol. 1, Austria; Conclusions XVI-1 vol. 1, Belgium; Conclusions XVI-1 vol. 1, Cyprus; Conclusions XVI-1 vol. 1, Czech Republic; Conclusions XVI-1 vol. 1, Germany; Conclusions XVI-1 vol. 1, Greece; Conclusions XVI-1 vol. 1, Iceland; Conclusions XVI-1 vol. 1, Ireland;

20 Ibid p. 23 
Due to the salient linkage, in certain cases the Committee defers its conclusion regarding Article 1(2) as long as satisfactory level of information has been provided by the Contracting Party on both areas ${ }^{21}$. Regarding the promotion of the European Code of Social Security, as Gabriella Battaini-Dragoni, Director General of Social Cohesion pointed out, "is seen as one of the core tasks of the Council of Europe in order to secure common values in the field of social cohesion in its member countries"22, therefore compliance with Article 12(1) is vital.

In the following part selected country profiles will be discussed in the light of the changes in the Committee's approach and the progress achieved by the Contracting Parties. Countries were selected on a highly arbitrary basis; however, priority was given to EU member states with relatively long (and/or interesting) history of non-compliance with the above mentioned articles.

\subsection{Case Law of the European Committee of Social Rights}

\subsubsection{Italy}

Italy ratified the European Social Charter in 1965 and the Revised European Social Charter in 1999, accepting 97 of its 98 paragraphs, including Article 1(2) and 12(1).

The Committee first examined the issue of "socially useful work" in Conclusions XIV-1 ${ }^{23}$, stating that under Act No. 608 of 28 November 1996, public sector administrations have the possibility to employing different categories of registered unemployed people to perform socially useful work. The Contracting Party's report stated that participation in this work does not mean the establishment of a formal employment relationship and the persons concerned will remain registered as unemployed while maintaining their unemployment benefits. However, a worker who refuses to participate loses his benefits by a sanction imposed by the Provincial Employment Directorate. An appeal could be filed with the Regional Employment Directorate. The Committee asked for more detailed information on the length of the period in which the unemployment benefit is suspended, the considerations taken into account when assigning a person to socially useful work and whether the appeal body is independent.

In its response ${ }^{24}$ the Contracting Party invoked Section 6 of Legislative Decree No. 468/1997 which regulates the matter. The decree provides that in assigning persons to such work, regard is to be had to qualifications and the professional requirements of the task with regard to the principal of equal opportu-

21 Conclusions XII-1, Denmark

22 Jason Nickless: European Social Code - Short Guide, Council of Europe Publishing, 2002, ISBN 92-871-4885-6 p. 5.

23 Conclusions XIV-1, Documents IDc-14-1-en, Article 1-2-2, Reference period 01/01/1994 $-12 / 31 / 1996$,

24 Conclusions XV 
nities. A person may refuse work if undergoes training with the relevant services or commuting of more than $50 \mathrm{~km}$ or of one hour by public transportation is required. The report provide details on the appealing process, stating that an administrative appeal against the cancellation of the unemployment benefit shall be filed within thirty days to the regional labor authorities and that such measure can also be brought before the administrative court.

However the report is silent on the duration of the period for which the unemployment benefit may be suspended in cases of unjustified refusal to accept socially useful work. Italy did not submit a report on Article 1(2) in $2003^{25}$ and therefore was found being not in conformity with the Charter. The 5th report on the Revised Charter was submitted in August $2005^{26}$. The subsequently published Conclusion in 2006 did not specifically come back the topic of socially useful work, however, regarding Article 12 of Social Security the Conclusions requests more information on the minimum level of all income-replacements benefits to assess their effectiveness, as due to the lack of an up-to-date figure for the poverty threshold defined as $50 \%$ of the median equivalised income, the Committee was unable to assess the adequacy of these benefits.

In Conclusion 2009 the Committee had to refer to the data of the Mutual Information System on Social Protection ${ }^{27}$. The MISSOC report shows that unemployment benefits are suspended in case of refusal of an appropriate job. Hence the Committee asks the next report to clarify the meaning of appropriate job and how it is assessed in individual cases, having noted that the adequacy of unemployment benefits, among others, also established by considering whether there is a reasonable initial period during which an unemployed person may refuse a job or a training offer not matching his/her previous skills without loosing his/her unemployment benefit. All in all, we need to wait for the coming evaluation of the Committee on that matter, as Conclusions in respect of the $11^{\text {th }}$ Report relating to Thematic Group 1 "Employment, training and equal opportunities" which - among others - deals with provisions concerning Article 1 will be published in December 2012.

\subsubsection{The United Kingdom ${ }^{28}$}

The United Kingdom ratified the European Social Charter in 1962 and has accepted 60 of the Charter's 72 paragraphs, including Article 1(2) and Article 12(1).

25 Conclusions 2006 European Social Charter (Revised)

26 The deadline of the 5th Report to the Council of Europe was 30 June 2005 (the reference period was 1 January 2003 to 31 December 2004 to the exception of Articles 1, 6, 12\$3, and 13, for which the reference period was from 1 January 2001 to 31 December 2004 due to the non-submission of the $3 \mathrm{rd}$ report on these provisions in one of the official languages).

27 MISSOC, Comparative table VIII for 2007 o n Unemployment at http://ec.europa.eu/ employment_social/missoc/missoc2007/tables_part_3_en.pdf

28 The United Kingdom introduced the terminology of 'job-seeker' for unemployed persons 
The Project Work employment program was introduced in October 1996. Long-term unemployed workers under the Project Work scheme might have been obliged to attend work experience programs or suffer a loss of unemployment benefits. In Conclusions XIV-1 the Committee asked more detailed information on the legal framework of the program, including suitability criteria and the sanctions. From Conclusions XV-1 we know that the Project Work program was terminated in May 1998 and was taken over by Section 19 of the Job-seekers Act. The Project Work program and subsequently the Job-seekers Act impose sanctions on those who fail to attend the Project Work, namely by the loss of the Jobseeker's Allowance. An independent body composed of Adjudication Officers has been called upon to decide the sanction and job-seekers have the right to appeal against its decision to the Social Security Appeal Tribunal. The report referred by Conclusion XVI-1 further specifies the sanction stating that it implies the loss of two weeks' benefits on the first occasion and of four weeks' benefit on the second occasion. It also elaborated on the hardship payment that is available from the third week of a four week sanction and earlier to certain more vulnerable groups (like pregnant women or persons with disabilities).

Pursuant to the Committees request on more details regarding the criteria used in evaluating the job-seekers bona fide and the suitability of their reasons in case they refuse to take up a certain employment or training, the report called up Section 73(2) of the Job-seekers Act which refers to reasons of health, religion and conscientious objections, caring responsibilities and excessive length of travel. With regard to the above information, the Committee noted that jobseekers cannot refuse to take up employment even for a short time, on the ground that it does not correspond to their occupational qualification, therefore considered that the situation does not comply with Article 1(2) of the Charter. Having reviewing the Conclusions, the British Government pointed out that the law actually allows the jobseekers to refuse an offer not matching their occupational qualification for a period of 13 weeks, and only after that time has expired they are liable to sanctions involving suspension of their unemployment benefits. Hence, in 2004 in Conclusions XVII-1, the Committee acknowledged that the situation is in conformity with Article $1(2)^{29}$.

With regard to Article 12 on Rights to Social Security, Conclusions XVIII-1 noted that the Contracting Party's report on unemployment benefit is well elaborated. The report indicated that jobseekers are eligible for contributory based Jobseeker Allowance, and in case it is insufficient for a particular beneficiary, the unemployed may be provided with the income based Jobseeker Allowance. The latter one is completed by a series of other support measures concerning housing, tax, etc. However the Committee came to the conclusion, that regarding the

first to enhance the importance the duty of active cooperation. Subsequently Hungary has changed its terminology too (from 'munkanélküli' to 'álláskeresö).

29 Conclusions XVII-1 Vol. 2., p. 20 
poverty threshold of EUR 748 per month ${ }^{30}$, the level of the contributory based Jobseeker Allowance for a single person (EUR 476 in the reference period) was inadequate, therefore is not in conformity with Article 12(1). The Committee also pointed out that only $15 \%$ of jobseekers receive contributory based Jobseeker Allowance. Since no changes were made in the social security scheme, in Conclusions XIX-2 of 2009 the Committee concluded that the situation in the United Kingdom is once again not in conformity with Article 12(1) of the Charter on the ground that the contributory Jobseeker's Allowance for single persons is manifestly inadequate. The next Conclusions evaluating the $31^{\text {st }}$ Report on Thematic Group 1 regarding Employment, Training and equal opportunities will be published in December 2012.

\subsubsection{Denmark}

Denmark ratified the European Social Charter in 1965 and has accepted 45 of the 72 paragraphs of the Charter including Article 1(2) and Article 12(1). Denmark has signed, but not yet ratified the Revised Charter ${ }^{31}$.

Regarding the Danish system of unemployment benefits, in its conclusions of XIV-1 the Committee noted that as from 1996, unemployment benefit claimants under the age of 25 having been unemployed for six months and not having completed a qualifying education, have the right and the obligation to complete at least eighteen months of education ${ }^{32}$. Pursuant to the Committee's request on more information on the scheme with a special focus on the possibility and consequences of refusal of participation, the Contracting Party elaborated on the details $s^{33}$. The report stated that the payment of unemployment benefits is dependent on the satisfaction of three conditions, namely to be a member of the Unemployment Insurance Fund for at least 12 months, to be registered as a job seeker with the public employment services and to accept the obligation to be available for work. Act No. 592 of $1999^{34}$ on unemployment insurance states that unemployed refusing the offered suitable work without adequate cause are loosing their unemployment benefits. Also, it defines a suitable work as a work within the occupational field for which the worker has been trained or in which he/she was previously worked, its location can be reached in less than 3 hours of transportation per day, and the wage shall correspond to the levels set within collective agreements. Moreover, the jobseeker shall cooperate with the public

30 In 2003, defined as $50 \%$ of median equivalised income and as calculated on the basis of the Eurostat at-risk-poverty threshold value. At-risk poverty rate is an indicator reflects the percentage of people with an equivalised disposable income below the 'at-risk-of-poverty threshold?. The at-risk-of poverty threshold is set for each country at $60 \%$ of the national median equivalised disposable income.

31 Also ratified the Additional Protocol providing for a system of collective complaints.

32 Conclusions XIV-1 Vol. 2., Report No. 17

33 Conclusions XVI-1 Vol. 1., Report No. 21.

34 As amended by Act. No. 603 of 2001 
employment services in a formulation of an individual action plan. A refusal to cooperate or to accept training provided for in the action plan may also entail suspension of the benefit. After three months of unemployment within the six last months, the jobseeker must accept so called reasonable work ${ }^{35}$. The evaluation of what is reasonable shall be viewed inter alia according to the length of unemployment of the person concerned. Regarding the appeals, the decision on suspension of benefits can be appealed before the Labor Marker Appeals Board, composed of a chairman appointed by the Queen, one each from the trade unions and employers organizations and two persons appointed by the Minister of Labor. Before deciding on conformity with Article 1(2), the Committee requested more information on the interpretation given in practice to the concept of reasonable work.

In Conclusions XVII-1 of 2007, the Committee reserved its conclusions regarding the loss of unemployment benefit in accordance to information received under Article 12. There, the Committee noted that the social security scheme has been changed. The maximum benefit period is henceforth four years within a reference period of six years.

In its next report the Danish Government only stated that the term "reasonable" means work which may be outside the occupational field of the unemployed person. The purpose of this change was to increase occupational mobility. Moreover, from a labor market perspective it would facilitate the placement of unemployed persons in local areas with labor shortages. However, the availability rules were subsequently amended by Act No. 1035 of 17 December 2002. The changes entailed, inter alia, that unemployed persons shall be available for reasonable work from the first day of unemployment and that he/she has an obligation to actively seek work, including during participation in activation measures. Henceforth, the Committee considered the new rules on availability to be very stringent, virtually compelling unemployed persons on pain of loss of benefits to accept a job regardless of the occupational field from the first day of unemployment. The Committee held that one of the aims of an unemployment benefit system is to offer unemployed persons adequate protection during at least an initial period of unemployment from the obligation to take up any job irrespective of occupational field, precisely with a view to giving them the opportunity of finding a job which is suitable taking into account their individual preferences, skills and qualifications. However desirable it may be for the labor market authorities to channel surplus workforce into areas with labor shortages, unemployed persons should be treated with due respect or their professional, social and family status and not as ordinary laborers, physically and mentally fit for any job ${ }^{36}$. Nevertheless, pending receipt of the information requested under Article 1(2), the Committee reserved its position and deferred its conclusion.

35 Section 63(2) of the Act No. 592 of 1999

36 Conclusions XVII-1

(C) Palacký University Olomouc, Czech Republic, 2012. ISSN 1213-8770 (print), ISSN: 2464-6601 (online). 
In its subsequent report in 2009, the Danish Government pointed out that all employable unemployed persons must draw up a CV describing their own qualifications and previous work history. Within at the latest one month since their last employment, this CV should be fed into the digital CV Bank which is used by all relevant labor market actors to ensure an effective and precise matching of job vacancies and jobseekers. Moreover, before a job offer is actually made, a series of preventive steps are undertaken including: (i) consultation between the potential employer and the Public Employment Service to verify whether the best suited has actually been chosen; (ii) pre-interviewing of the potential employee on the vacancy that might be offered. According to the Government, this procedure allows the unemployed person who might be selected for the job offer to decline the offer before it is officially made. Thus, according to the Government, when an official offer is made in practice the unemployed person will not refuse it as it will match with his/her professional history. The Committee asked the report which was due in February 2012 to indicate how often an official job offer is declined and unemployment benefits are suspended. The report should also contain information on any relevant case law. Meanwhile, the Committee reserves its position as to the actual guarantee of the unemployment risk for which every worker has contributed during his working activity ${ }^{37}$. Pending receipt of the requested information, the Committee once again deferred its conclusion until the next Conclusions which will be published in December 2012.

\subsubsection{The Netherlands}

The Netherlands ratified the European Social Charter in 1980 and the Revised Charter in 2006, accepting 97 of its 98 paragraphs.

As regards unemployment benefits in particular, adequacy is also assessed, inter alia, by considering whether there is a reasonable initial period during which an unemployed person may refuse a job or a training offer not matching his/her previous skills without losing his/her unemployment benefits. In Conclusions XVIII-1, the Committee asked the Netherlands to clarify the situation in this regards.

In its reply the report refers to the report on the European Code of Social Security, which explains that unemployment benefits may not be granted to persons defined as "culpable unemployed" who are predominantly to blame for his/ her unemployment. The Committee noted that the list of grounds under which the person may be considered as "culpably unemployed" is extensive. The Committee also noted that the number of appeals on cases where unemployment benefit was not granted due to classification of the person as "culpably unemployed" was high, over two-thirds of the cases, which indicates that is majority of cases the claimants did not agree with the administrative decisions made by authorities. The Committee asked for detailed explanation of the various

37 Conclusions XIX-2 (2009) 
grounds of considering somebody as "culpably unemployed". Pending receipt of the report, the Committee deferred its conclusion. The next Conclusions including the evaluation of Article 1 will be published in December 2012.

\section{The Hungarian Public Work Program}

Hungary ratified the European Social Charter in 1999 and the Revised European Social Charter in 2009, accepting 60 of the Revised Charter's 98 articles, including Article 1(2) and Article 12(1).

2011, as a part of the 2011-2015 Convergence Program, the government made drastic amendments in the public law program, triggering the attention of the European Commission and civil society actors. For better understanding on the differences of the new program, a short introduction to the history of public work will be given.

\subsection{The Past}

The origins of the public work program in Hungary go back to the 1940s. The first government-initiated program, organized by the People and Family Protection Fund (ONCSA), was aiming to help families engaged in agricultural activities in the rural Hungary. However, it eventually became a tool in the government's hand to execute its policy of ethnic and racial discrimination ${ }^{38}$. After WWII, during the communist power, work (possibly within the collective property) was a legal duty, sanctioned by criminal and administrative sanctions. Unemployment started to become a problem with the starting emergence of the market economy in the late 1980s. To reintegrate to the labor market those, who lost their job "through not their own fault", the government launched a "work program for public benefit" in 1987. The first public work program in its contemporary meaning began in 1996 to tackle long-term unemployment ${ }^{39}$. This program went under major reforms in 2000, when the regular social benefits first became conditional to the participation in the public work scheme. In 2006 the program was renamed to "Integration Program"; the change in the name was triggered by the new conditions related to a more intensive cooperation desired from the participants. The scheme was again amended in 2007 and in 2008 , when in 2009 a new program, 'Road to Work' was launched, targeting low educated persons suffering from long-term unemployment.

The program introduced a new scheme in finances, namely a substantial increase of the budget available for public work programs managed by local governments. Those, who drawn regular social benefits but were capable of working,

38 Szikra, Dorottya A szociálpolitika másik arca. Fajvédelem és produktív szociálpolitika az 1940-es évek Magyarországán. [The Other Face of Social Policy. Racism and Productive Social Policy in the 1940s' in Hungary.] In Századvég, Uj folyam, 48/2008. 2. pp 35-77., 2008.

39 Labor Ministry Decree No. 6/1996. (VII. 6.), quoted by Csoba, Judit In: Esély 2010/1 p. 6. 
were redirected to the new scheme and when no suitable public work was available for them, they were entitled to a so called 'availability allowance', equal to the minimum amount of old-age pension (HUF 28,500 or EUR 97 per month). Those, who were not willing to take up the work offered, were excluded from the social benefit scheme. Hundreds of pages of researches ${ }^{40}$ have shown the inefficacy of 'Road to Work' after scrutinizing its effect on the long-term unemployment figures. Most of the studies marked that 'Road to Work' did not introduce significant novelty compared to the former schemes, therefore it was as ineffective as the previous ones ${ }^{41}$.

\subsection{The Present}

\subsubsection{Terms and Conditions}

Disregarding the often changing titles of the benefits, from the Committee's approach the Hungarian system looks as follows. In case of unemployment, there are basically three types of allowances are available: the job-seekers allowance, the employment supplement ${ }^{42}$ allowance and the pre-retirement allowance ${ }^{43}$.

The job-seekers allowance is an income-replacement benefit whereas the entitlement is based on previous contribution to the unemployment insurance scheme for at least 360 days in 3 consecutive years. The duration of payment depends on the length of contribution but cannot be longer than 90 days (before the amendmenys, it was 270 day altogether).

Only those workers are entitled to claim such benefit to whom the Public Employment Agency cannot offer suitable employment. The definition of suitable employment is given in Article 25(2) b)-e) of Act No. IV of 1991. According to the law, the offered job shall be accepted when the job-seeker is i) fit to work in the light of his/her health conditions, ii) the foreseeable wage or salary reaches the amount of the job-seeking allowance, or if the amount of the job-seeking allowance is smaller than the statutory minimum wage, it reaches the amount of the statutory minimum wage, iii) the duration of the daily commutation between the workplace and the place of residence by means of public transport does not exceed three hours, or two hours in the case of women raising children under the age of 10 or single men raising children under the age of 10 , and iv) the jobseeker is engaged in a labor relation.

40 Couple of hundreds could be found in the dedicated issues of Munkaeröpiaci tükör, 2010. Közelkép: a válság munkapiaci hatásai. Budapest, MTA KTI, 2010, Edt. Kézdi Gábor, and Esély, 2010/1

41 Judit Csoba: The Old and New Systems of Public Employment (On the way in the "Ways to Work" Program); Esely 2010/1

42 Previously called job-seeker aid and later on wage supplement benefit

43 Pre-retirement allowance will not be discussed this time. 
It is important to note that Article 25 Para. 2 a) which stated that an unemployed person could refuse the job offered in the initial period without loosing the benefit if it did not correspond to the level of qualification of the job-seeker, or any other school qualification that has been offered by the governmental employment body and can be attained with the use of the training opportunity for the given level of qualifications, or it does not correspond to the level of qualification relating to the job that was last occupied for at least six months was abolished by the amending law ${ }^{44}$.

To be entitled for the employment supplement allowance, the unemployed person shall register to the public work program. Only those can be registered to the system who are willing to undertake the duty of cooperation with the Public Employment Agency. The registered workers are either offered a job within the program, or, when no job is available, are entitled for the employment supplement benefit. Refusal of the job without loosing the benefits is possible only on the basis of one's health condition or of overly burdensome commuting time. ${ }^{45}$

Moreover, employment supplement benefit is paid only to individuals who can certify at least 30 days of employment each year (participation in a public work scheme, seasonal work performed in the framework of simplified employment or work performed in any other form like voluntary work).

If the unemployed person refuses to take up a 'suitable employment', quits the job or the employer terminates the employment with an immediate effect ${ }^{46}$, the payment of the employment supplement benefit may be suspended until the pre-conditions for entitlement are newly completed. Also it shall be noted that under Act III of 1993 on social administration and social assistance further requirements may be described by municipal decrees like keeping the direct residential environment in order ${ }^{47}$. Those who fail to meet the criteria set forth in the municipal decree, will also lose eligibility for the employment supplement benefit for a month.

\subsubsection{The amount of social benefits}

The amount of the job-seekers allowance is dependent on the contribution base of the previous four calendar quarters, while the statutory minimal wage for public work is regulated by Government Decree 170/2011 (VIII.24.), stating that the minimal wage for full time public work is HUF 71800 gross per month (equals to about HUF 48,000 net, which is around EUR 146) for unskilled work

44 Act No. CLXXI of 2010, Art. 105 e), not in force since Jan. 1, 2011.

45 Act No. IV of 1991, Art. 54 Paras 10-10c

46 Act. No. III of 1993 Art. 36 para 2

47 This authorization rises concerns about its conformity with human rights such as dignity or equality. For more on this see the statement of Eotvos Karoly Institution (only in Hungarian: http://www.ekint.org/ekint/ekint.news.page?nodeid=461; retrieved on 10 May, 2012) 
and it is HUF 92000 gross per month (EUR 313) for jobs requires at least secondary education. The amount of employment supplement benefit is HUF 22 800 (EUR 77.6) per month. It is important to see that the employment supplement benefit's amount is significantly lower than the statutory minimal wage of HUF $93000^{48}$.

The amount of social benefits one can apply for is now maximized. With other words, the regular social benefit and the employment supplement benefit together cannot be higher than the amount close to the minimal wage ${ }^{49}$, but it is not calculated per capita but per family. Job-seekers' allowance and employment supplement benefit may only be combined with family allowance and only one person per family is eligible to participate in the public work program (e.g. draw either wage for the work performed or the employment supplement benefit in case there is no job offered $)^{50}$.

\subsection{Evaluation of the program}

In the report on the Eradication of Forced Labor, the ILO Committee has considered that connecting the entitlement for benefits to the performance of work would not in itself constitute forced or compulsory labor. ${ }^{51}$ However, concerning the notions of "availability for work" and "suitable employment" of Article 20 of the Social Security (Minimum Standards) Convention, 1952 (No. 102), if the work required to be performed is not "suitable employment", it would constitute a form of forced labor ${ }^{52,53}$.

Regarding the European Social Charter, as it was discussed above, the Committee also emphasizes the importance of suitable employment and if the jobseeker cannot refuse to take up employment on the ground that it does not correspond to their occupational qualification, the non-compliance with Article $1(2)$ of the Charter is stated ${ }^{54}$.

Already in Conclusions XIX-2 ${ }^{55}$ the Committee noted that the rate of the (back-then) job-seeker aid stand below the at-risk poverty threshold ${ }^{56}$ even

48 As of Jan $1,2012$.

49 The actual amount is calculated in a rather difficult way, multiplying the rate of allocated consumption of a family and the minimal wage by 0.9 ; calculations show that actual amount received is close to the minimal wage, currently HUF 93,000 or EUR 315.

50 Article 33 para 5 of Act No. III of 1993.

51 International Labor Conference, 96th Session, 2007 Report III (Part 1B) p. 70, emphasis is in the original.

52 Ibid.

53 Hungary has not yet ratified Convention No. 102.

54 Conclusions XIX-2, Italy

55 Conclusions XIX-2, Hungary, p. 70

56 According to the data of the Hungarian Central Statistical Agency, the amount of minimum of subsistence value calculated per household with one adult of active age is HUF 78,736 or EUR 265, which increases by $65 \%$ with each child. 
when defined as $40 \%$ of the equivalised income estimated at EUR 131 (EUR 164 as $50 \%$ ) by the Eurostat in 2007 , therefore it is not in conformity with the Article 12(1) of the Charter.

Therefore coming to the conclusion that worsening the conditions and lowering the amount of benefits has not brought Hungary closer to compliance is not an overstatement.

\section{Conclusions}

Unemployment is a highly complex area and it is affected by and connected to great many indicators, like economic growth, poverty, transfers, education, and social exclusion, just to name a few. This study started off with some striking data on rising poverty. Fur further elaboration it may be added that data also show that poverty is interlocked with factors such as low work activity and the effectiveness of social transfers ${ }^{57}$.

Low work activity refers to the ratio between the number of months that household members of working age $\mathrm{e}^{58}$ worked during the income reference year, and the total number of months that could theoretically have been worked by the same household members ${ }^{59}$. It naturally comes together with unemployment or rather, long-term unemployment ${ }^{60}$, the main target of public work programs $\mathrm{s}^{61}$. After the 2008 economic crisis, the unemployment ratio shot up on EU-27 level from $6.7 \%$ to $9.1 \%^{62}$, the long-term unemployment has risen from $3.0 \%$ to $4.1 \%$ in two years ${ }^{63}$. In the meanwhile, the long-term unemployment ratio in Hungary has been significantly worse: it was $4.1 \%$ in 2009 and went up as high as $5.2 \%$ in $2011^{64}$. It is a clear sign that the 'Road to work' program was unable to cope with the effect of the crisis to the labor market and it would not mean it itself that therefore the new scheme is also incompetent. However, if we look into the connected factors, it is very unlikely that the new program will be able to contribute to the reduction of poverty.

While overall at EU level of $8 \%$, severe material deprivation remained stable between 2009 and 2010, it has gradually increased in Hungary and in 2011 it

57 Statistics in focus 9/2012 Population and social conditions; Authors: Mélina ANTUOFERMO and Emilio DI MEGLIO, Data extracted on: 16.12.2011, ISSN 1977-0316, Catalogue number: KS-SF-12-009-EN-N, Eurostat

58 Aged 18-59, not being a student aged 18-24; Eurostat Unemployment Statistics, http:// epp.eurostat.ec.europa.eu/statistics_explained/index.php/Unemployment_statistics, data retrieved on 10 May, 2012. p. 4

59 Ibid.

60 Unemployment lasting for 12 months or more

61 See above at

62 Eurostat Unemployment Statistics, http://epp.eurostat.ec.europa.eu/statistics_explained/ index.php/Unemployment_statistics, data retrieved on 10 May, 2012.

63 Eurostat Long-term unemployment ration, Code: tisc 070

64 Ibid. 
was around $20 \%$. On the other hand, data show that adequate transfers have an important redistributive effect that helps to reduce the number of people who are at-risk-of-poverty. Naturally, the balance is better in countries where the expenditure on social protection ${ }^{65}$ reaches a higher percentage of the GDP. On EU-27 level this expenditure is average of $29.5 \%$, while in Hungary it is only $23.4 \%$.

Since Road to work program and its predecessors failed to lower the long term unemployment rate, it is clear that the solution cannot be achieved by public work. A public work program which forces people to take up any kind of work regardless of previous qualifications or occupations will not help their reintegration to the primary labor market. Significant cut-backs on the various unemployment benefits would certainly not help to decrease the number of people living on at-risk poverty level either. These measures are nothing but fragments without a comprehensive strategy. Without breaking the vicious cycle by introducing a complex social policy focusing on equal educational opportunities, alleviating deep poverty and raising the employment level of the unqualified, they only transfer liability from community to individual level and that will only further erode solidarity on all levels of the society, however, it would be most needed during a crisis.

65 It contains social benefits, which consist of transfers, in cash or in kind, to households and individuals to relieve them of the burden of a defined set of risks or needs; administration costs, which represent the costs charged to the scheme for its management and administration; other expenditure, which consists of miscellaneous expenditure by social protection schemes (payment of property income and other).

66 Eurostat, Code: tps00098 